\title{
The full greenhouse gas balance of an abandoned peat meadow
}

\author{
D. M. D. Hendriks, J. van Huissteden, A. J. Dolman, and M. K. van der Molen
}

Vrije Universiteit Amsterdam, Faculty of Earth and Life Sciences, Department of Hydrology and Geo-environmental Sciences, De Boelelaan 1085, 1081 HV Amsterdam, The Netherlands

Received: 20 December 2006 - Published in Biogeosciences Discuss.: 31 January 2007

Revised: 10 May 2007 - Accepted: 14 June 2007 - Published: 27 June 2007

\begin{abstract}
Globally, peat lands are considered to be a sink of $\mathrm{CO}_{2}$, but a source when drained. Additionally, wet peat lands are thought to emit considerable amounts of $\mathrm{CH}_{4}$ and $\mathrm{N}_{2} \mathrm{O}$. Hitherto, reliable and integrated estimates of emissions and emission factors for this type of land cover have been lacking and the effects of wetland restoration on methane emissions have been poorly quantified. In this paper we estimate the full greenhouse gas (GHG) balance of a restored natural peat land by determining the fluxes of $\mathrm{CO}_{2}, \mathrm{CH}_{4}$ and $\mathrm{N}_{2} \mathrm{O}$ through atmosphere and water, while accounting for the different Global Warming Potentials (GWP's).
\end{abstract}

The site is an abandoned agricultural peat meadow, which has been converted into a wetland nature reserve ten years ago, after which the water level was raised. GHG fluxes were measured continuously with an eddy covariance system $\left(\mathrm{CO}_{2}\right)$ and flux chamber measurements $\left(\mathrm{CH}_{4}\right.$ and $\left.\mathrm{N}_{2} \mathrm{O}\right)$. Meteorological and hydrological measurements were collected as well. With growing seasons of respectively 192, 168 and 129 days, the annual net ecosystem exchange of $\mathrm{CO}_{2}$ (NEE) was $-446+ \pm 83 \mathrm{~g} \mathrm{C} \mathrm{m}^{-2} \mathrm{yr}^{-1}$ for 2004, $-311 \pm 58 \mathrm{~g} \mathrm{C} \mathrm{m}^{-2} \mathrm{yr}^{-1}$ for 2005 and $-232 \pm 57 \mathrm{~g} \mathrm{~m}^{-2} \mathrm{yr}^{-1}$ for 2006. Ecosystem respiration $\left(\mathrm{R}_{\mathrm{eco}}\right)$ was estimated as $869 \pm 668 \mathrm{~g} \mathrm{C} \mathrm{m}^{-2} \mathrm{yr}^{-1}$ for $2004,866 \pm 666 \mathrm{~g} \mathrm{C} \mathrm{m}^{-2} \mathrm{yr}^{-1}$ for 2005 and $924 \pm 711 \mathrm{~g} \mathrm{C} \mathrm{m}^{-2} \mathrm{yr}^{-1}$ for $2006 . \mathrm{CH}_{4}$ emissions from the saturated land and water surfaces were high compared to the relatively dry land. Annual weighted $\mathrm{CH}_{4}$ emissions were $31.27 \pm 20.40 \mathrm{~g} \mathrm{C} \mathrm{m}^{-2} \mathrm{yr}^{-1}$ for 2005 and $32.27 \pm 21.08 \mathrm{~g} \mathrm{C} \mathrm{m}^{-2} \mathrm{yr}^{-1}$ for $2006 . \mathrm{N}_{2} \mathrm{O}$ fluxes were too low to be of significance. The water balance of the area was dominated by precipitation and evapotranspiration and therefore fluxes of carbon and $\mathrm{CH}_{4}$ through seepage, infiltration and drainage were relatively small $\left(17.25 \mathrm{~g} \mathrm{C} \mathrm{m}^{-2} \mathrm{yr}^{-1}\right)$. The carbon-balance consisted for the largest part of $\mathrm{CO}_{2}$ uptake, $\mathrm{CO}_{2}$ respiration and $\mathrm{CH}_{4}$ emission from water saturated

Correspondence to: D. M. D. Hendriks

(dimmie.hendriks@falw.vu.nl) land and water. $\mathrm{CO}_{2}$ emission has decreased significantly as result of the raised water table, while $\mathrm{CH}_{4}$ fluxes have increased. In GWP's the area was a small net GHG sink given as $\mathrm{CO}_{2}$-equiv. of $-86 \mathrm{~g} \mathrm{~m}^{-2} \mathrm{yr}^{-1}$ (over a 100 -year period).

\section{Introduction}

Human activities have caused an increase in atmospheric concentrations of GHG's since the pre-industrial era by $30 \%$ for $\mathrm{CO}_{2}$, by $150 \%$ for $\mathrm{CH}_{4}$ and by $17 \%$ for $\mathrm{N}_{2} \mathrm{O}$ (IPCC, 2001). The European land surface is thought to be absorbing a significant amount of the current industrial $\mathrm{CO}_{2}$ emissions (Janssens et al., 2005) and to be releasing over $40 \%$ of the European $\mathrm{CH}_{4}$ and $\mathrm{N}_{2} \mathrm{O}$ emissions (IPCC, 2001). However, reliable estimates of emissions and emission factors are still lacking.

Unlike industrial emissions, emissions related to land use are controlled by a combination of biological, climatological and management factors and show large spatial and temporal variability. To be able to understand the effects of the rising GHG concentrations in the atmosphere as well as the variability and vulnerability of the natural carbon cycle, knowledge of the emission and uptake of carbon by terrestrial surfaces is necessary.

Peat lands in Europe have formed a large sink of atmospheric $\mathrm{CO}_{2}$ since the last glacial maximum. This is the result of their ability to accumulate organic matter at a higher rate than decomposition takes place, mainly as a result of high water tables and therefore anaerobic conditions. Due to these generally wet and anaerobic conditions peat lands are also significant emitters of the $\mathrm{GHG} \mathrm{CH}_{4}$ and sometimes $\mathrm{N}_{2} \mathrm{O}$ (Drösler et al., 2007). The GWP's of $\mathrm{CH}_{4}(\sim 23$, over 100 years) and $\mathrm{N}_{2} \mathrm{O}(\sim 300$, over 100 years) are significantly higher than that of $\mathrm{CO}_{2}$ (1 by definition) (IPCC, 2001).

Published by Copernicus Publications on behalf of the European Geosciences Union. 


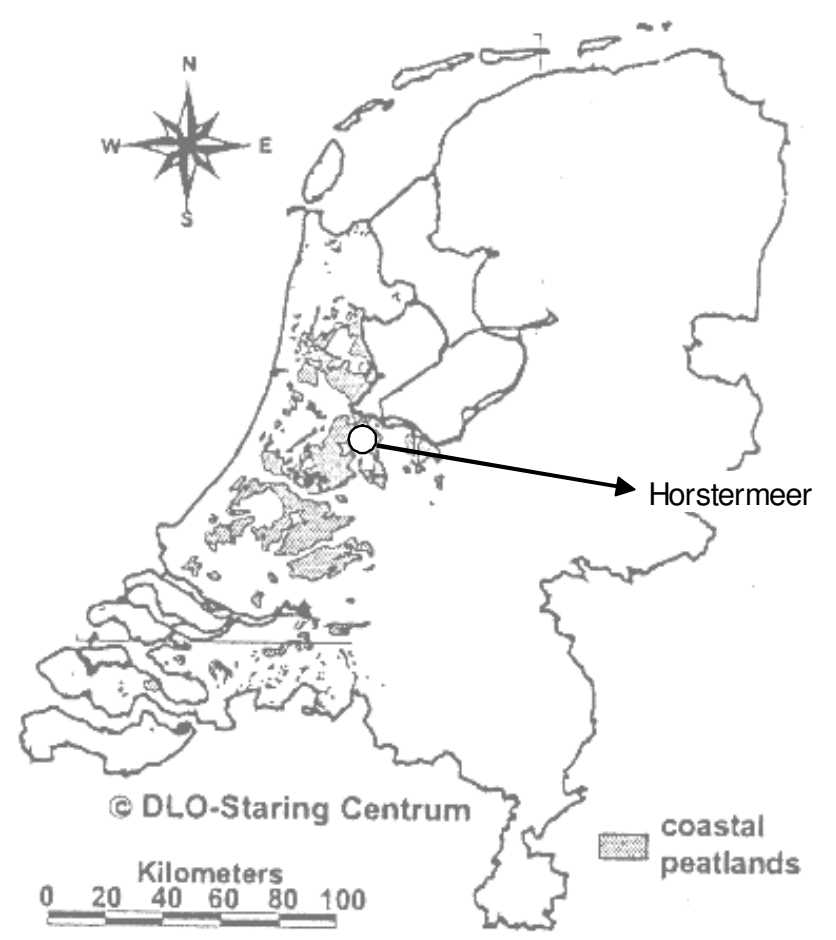

Fig. 1. Current distribution of peat soils in the western part of the Netherlands (SC-DLO 1992) and location of Horstermeer research site.

Over the last 100 years many peat areas in Europe have been transformed into agricultural land with artificially low water tables. This resulted in an increase of peat oxidation and peat ecosystems have become a strong source of $\mathrm{CO}_{2}$ (Langeveld et al., 1997). Peat oxidation can be reduced and peat areas can be turned into sinks of $\mathrm{CO}_{2}$ if water levels are increased as suggested by a host of literature (e.g. Burgerhart, 2001; Van den Bos et al., 2003). In the western part of the Netherlands $10 \%$ of the land $\left(1.6 \times 10^{3} \mathrm{~km}^{2}\right)$ consists of peat soils (Fig. 1). Currently, most of these soils are managed and have artificially low water tables. Plans exist to convert these agricultural areas into wetland nature by raising the water tables and reducing agricultural use both through extensification and restoration, depending on the area. This change will probably turn the area from a $\mathrm{CO}_{2}$-source in a $\mathrm{CO}_{2}$-sink and alter the emissions of $\mathrm{CH}_{4}$ and $\mathrm{N}_{2} \mathrm{O}$.

To compile a full GHG balance of a peat land and to understand the mechanisms and processes that affect this balance, comprehensive and long term measurements are needed. All components of that balance should be studied, including the lateral and vertical transport of dissolved carbon and methane out of the system. Currently, only few annual records of $\mathrm{CO}_{2}, \mathrm{CH}_{4}$ and $\mathrm{N}_{2} \mathrm{O}$ measurements in peat lands are available (Regina et al., 2004; Treat et al., 2007 and Alm et al., 1999). Besides, very few comprehensive integrated measurement campaigns have been carried out (Roulet et al., 2007; Soussana, 2007; Drösler et al., 2007).
This paper describes the full spectrum of GHG's in an abandoned peat meadow area in the western part of the Netherlands which has been transformed from an agricultural area into a wetland nature reserve by raising the water level. Our main goal was to quantify all sinks and sources of GHG's in the area year round and to assess the full GHG balance. This implied, estimating not only the vertical losses and gains through atmosphere, but also vertical and lateral losses of dissolved gases through water and taking into account the different GWP's.

\section{Site description}

The Horstermeer site is located on former agricultural land in a drained natural lake in the central part of the Netherlands $\left(52.144^{\circ} \mathrm{N}, 5.043^{\circ} \mathrm{E}\right.$, Fig. 1). The research site has been taken out of agricultural production more than 10 years ago, and has developed into semi-natural grassland. The two meter thick soil consists of peat, overlain with organicrich lake deposits (Table 1) and is overlying eolian sands of Pleistocene age. After the site was taken out of agricultural production, the ditch water table has been raised to approximately $10 \mathrm{~cm}$ below the land surface. Large parts of the Horstermeer polder are subject to strong groundwater seepage from surrounding lake areas and Pleistocene ice pushed ridges. At the measurement location seepage is largely reduced and even infiltration occurs as a result of the high water table. The surface of the research area consists of $10 \%$ of ditches, of $20 \%$ of land that is saturated annual (mostly alongside the ditches) and of $70 \%$ of relatively dry land with a fluctuating water table (between 0 to $40 \mathrm{~cm}$ below the soil surface) and an aerated top-layer. Management consists only of regulation of the ditch water table; no cattle grazing or harvesting takes place, the only removal of vegetation consists of sporadic grazing by roe deer. Vegetation consists of different types of grasses (dominant species Holcus lanatus, Phalaris arundinacea, Glyceria fluitans), horsetail (Equisetum palustre, fluviatile) reeds (Phragmites australis, Typha latifolia) and high forbs (Urtica diocia, Cirsium arvense, palustre). Main characteristics of the site are given in Table 2 .

\section{Methods and instrumentation}

All measurements are carried out over the period 1 January 2004 until 31 December 2006, unless mentioned differently.

3.1 Hydrological measurement techniques, data acquisition and processing

Hydrological measurements included water table recordings of the pressure heads using pressure sensors installed in access tubes in the clayey peat top layer at two locations and 
Table 1. Description of a soil profile at the measurement site.

\begin{tabular}{|c|c|c|c|c|c|c|c|c|}
\hline $\begin{array}{l}\text { Depth } \\
\text { (m) }\end{array}$ & Color & Material & Decomposition & $\begin{array}{l}\text { Roots } \\
\left(\mathrm{kg} \mathrm{m}^{-3}\right)\end{array}$ & $\mathrm{pH}$ water & $\begin{array}{l}\mathrm{pH} \\
(\mathrm{KCl})\end{array}$ & $\begin{array}{l}\text { Organic matter } \\
\text { weight }(\%)\end{array}$ & $\begin{array}{l}\text { Permeability } \\
\left(\mathrm{cm} \mathrm{day}^{-1}\right)\end{array}$ \\
\hline $0-20$ & $7.5 \mathrm{YR} 2 / 3$ & clayey peat & strong & many, 4.1 & 5.7 & 5 & 39.4 & 4.04 \\
\hline $20-30$ & 7.5YR2/2 & clayey peat & strong & 2 & 5.8 & 5.1 & 45.1 & 0.16 \\
\hline $30-48$ & $5 \mathrm{Y} 2 / 2$ black & gyttja & partly & 2 & 5.5 & 5.2 & 32.5 & \\
\hline $48-68$ & 2.5Y3/1 greenish & clayey gyttja & slightly & few & 6 & 5.6 & 36.4 & \\
\hline $68-128$ & $10 \mathrm{YR} 2 / 3$ & peaty gyttja & & none & 5.8 & 5.3 & 50.3 & \\
\hline $128-178$ & 2YR1.7/1 & reworked peat, clay & & & 6.1 & 5.6 & 73.1 & \\
\hline $178-210$ & $10 \mathrm{YR} 2 / 3$ & compact peat & & & & & & \\
\hline $210-250$ & & sand & & & & & & \\
\hline
\end{tabular}

Table 2. Site description: elevation, roughness length $\left(z_{0}\right)$, zero plane displacement $(d)$, reference height $\left(z_{\text {ref }}\right)$, rainfall, temperature, water level, electrical conductivity (EC), pH, soil type and C/N-ratio, biomass and dominant vegetation types. Data observed over 2005 and 2006.

\begin{tabular}{|c|c|}
\hline Site & Horstermeerpolder (NL-hor) \\
\hline Location & $52^{\circ} 11^{\prime} 44^{\prime \prime} \mathrm{N}, 05^{\circ} 44^{\prime} 33^{\prime \prime} \mathrm{E}$ \\
\hline Elevation (m above NAP) & -2.2 \\
\hline$z_{0}(\mathrm{~m})$ & 0.04 \\
\hline$d(\mathrm{~m})$ & 0.5 \\
\hline$z_{\text {ref }}(\mathrm{m})$ & 4.3 \\
\hline Mean annual Rainfall (mm year $\left.{ }^{-1}\right)$ & 797 (average over longer period) \\
\hline Mean annual Temperature $\left({ }^{\circ} \mathrm{C}\right)$ & 9.8 (average over longer period) \\
\hline soil water level winter & $\begin{array}{l}\text { along ditches: } 0 \text { to } 5 \mathrm{~cm} \text { above soil surface central part of } \\
\text { field site: } 0 \text { to } 10 \mathrm{~cm} \text { below soil surface }\end{array}$ \\
\hline soil water level summer & $\begin{array}{l}\text { along ditches: } 0 \text { to } 2 \mathrm{~cm} \text { below soil surface central part of } \\
\text { field site: } 5 \text { to } 45 \mathrm{~cm} \text { below soil surface }\end{array}$ \\
\hline Mean EC $\left(\mu \mathrm{S} \mathrm{m}^{-1}\right)$ & soil water: 757; ditch water: 677; deep groundwater: 601 \\
\hline Mean $\mathrm{pH}$ & soil water: 6.85 ; ditch water: 7.09 ; deep groundwater: 7.07 \\
\hline Soil (FAO) & Eutric Histosol \\
\hline $\mathrm{C} / \mathrm{N}$-ratio of peat in top 10 to $50 \mathrm{~cm}$ & 7.3 to 41.3 (15.5 on average) \\
\hline Height of vegetation $(\mathrm{m})$ & 0.2 to 2.5 ( 0.5 on average $)$ \\
\hline Mean biomass $\left(\mathrm{kg} \mathrm{m}^{-2}\right)$ & $\begin{array}{l}\text { living biomass }=0.434 \\
\text { dead biomass }=0.998\end{array}$ \\
\hline Vegetation types (fractional cover) & $\begin{array}{l}\text { Phragmites australis }(34 \%) \text {, Holcus lanatus }(15 \%) \text {, } \\
\text { Agrostis stolonifera }(14 \%) \text {, Phalaris arundinacea }(8 \%) \text {, } \\
\text { Juncus effusus }(5 \%) \text {, Urtica dioica }(4 \%) \text {, Typha latifolia } \\
(3 \%) \text {, Equisetum palustre }(3 \%)\end{array}$ \\
\hline
\end{tabular}

in the Pleistocene sand aquifer at one location. Also, the water level in the drainage ditch was measured with a pressure sensor in an access tube. Using the level of the ditch water relative to the height of the overflow weir, discharge could be calculated continuously (Van de Griend, 1989). Water levels were logged on an hourly basis and were all set to the same reference level before further analysis. Outliers and spikes were removed from the dataset. Finally gaps were filled with average values over the surrounding time period. No gaps larger than 24 hours were encountered.
Water samples were taken from the pore water in the clayey peat, the groundwater from the sand aquifer and from the ditch water to determine total carbon (TC) and dissolved $\mathrm{CH}_{4}$ in the three water types. TC was determined as the sum of total organic carbon (TOC), total inorganic carbon (TIC). Samples were collected using glass filters, installed in the soil or ditch water at $0.2 \mathrm{~m}$ depth intervals, and connected to the surface using small diameter Teflon tubes. In the soil these filters were installed in a small diameter borehole, separated from each other by bentonite plugs. The soil filters were installed at three locations, the ditch filters at two 
Table 3. Ranges of values used in the quality check of the meteorological data.

\begin{tabular}{|c|c|c|c|}
\hline variable & unit & minimum value & maximum value \\
\hline Wind speed (horizontal*vertical) $(u w)$ & {$\left[\mathrm{m}^{2} \mathrm{~s}^{-2}\right]$} & -0.10 & 0.10 \\
\hline Air temperature $(T)$ & {$\left[{ }^{\circ} \mathrm{C}\right]$} & -10 & 50 \\
\hline Carbon dioxide $\left(\mathrm{CO}_{2}\right)$ concentration & [ppm] & 330 & 600 \\
\hline Water vapor $\left(\mathrm{H}_{2} \mathrm{O}\right)$ concentration & {$\left[\mathrm{kg} \mathrm{m}^{-3}\right]$} & 0.002 & 0.018 \\
\hline Carbon dioxide $\left(\mathrm{CO}_{2}\right)$ flux & {$\left[\mu \mathrm{mol} \mathrm{m}^{-2} \mathrm{~s}^{-1}\right]$} & -40 & 30 \\
\hline Sensible heat flux $(L E)$ & {$\left[\mathrm{W} \mathrm{m}^{-2}\right]$} & -400 & 1000 \\
\hline Sensible heat flux $(H)$ & {$\left[\mathrm{W} \mathrm{m}^{-2}\right]$} & -100 & 300 \\
\hline Incoming and emitted longwave radiation ( $L W_{\text {in }}$ and $\left.L W_{\text {out }}\right)$ & {$\left[\mathrm{W} \mathrm{m}^{-2}\right]$} & 50 & 700 \\
\hline Incoming and reflected shortwave radiation ( $S W_{\text {in }}$ and $\left.S W_{\text {out }}\right)$ & {$\left[\mathrm{W} \mathrm{m}^{-2}\right]$} & -50 & 1200 \\
\hline Air pressure $\left(P_{\text {air }}\right)$ & {$[\mathrm{kPa}]$} & 70 & 130 \\
\hline Bole temperature $\left(T_{\text {bole }}\right)$ & {$\left[{ }^{\circ} \mathrm{C}\right]$} & -40 & 70 \\
\hline
\end{tabular}

locations. Samples were taken using a syringe for drawing up the water, after which the sampling tube was connected to a vacuum exetainer using a three-way stopcock. All sampling was performed anaerobic. TC in the water samples was analyzed with a Dohrmann DC-190 TC analyzer and dissolved $\mathrm{CH}_{4}$ was analyzed by gas chromatography (Hewlett Packard 5890A, Avondale PA, USA) of the gas-filled headspace of the exetainers. The total $\mathrm{CH}_{4}$ concentration in the sampled volume was calculated using the gas-water solubility coefficient.

3.2 Meteorological measurement techniques, data acquisition and processing

Eddy covariance measurements of $\mathrm{CO}_{2}$ concentration, water vapour, wind speed and air temperature were performed with a Licor 7500 open path infrared gas analyser (LI-COR Lincoln, NE, USA) and a Windmaster Pro 3 axis Ultrasonic Anemometer (GILL Instruments Limited, Hampshire, UK) directed into the main wind direction. Licor and Anemometer were installed at $4.3 \mathrm{~m}$ above the surface. Data were logged digitally on a handheld computer at a rate of $10 \mathrm{~Hz}$ (Van der Molen et al., 2006). The EUROFLUX methodology (Aubinet et al., 2000) was applied to the eddy covariance data to calculate the fluxes of momentum, sensible and latent heat and $\mathrm{CO}_{2}$ on a thirty minute basis. The method of Nakai et al. (2006) was used to apply the angle of attack dependent calibration (Gash and Dolman, 2003; Van der Molen et al., 2004).

Additional micrometeorological measurements were executed at a tower close by the eddy covariance set up. Air pressure was measured (SensorTechnics pressure transducers, model 144SC1216BARO) as well as wet and dry bulb temperatures (Fast response Chromel-Constantan thermocouple with an effective diameter of $0.2 \mathrm{~mm}$, made at the Vrije Universiteit Amsterdam). Incoming and reflected shortwave radiation (Kipp and zonen, Delft, the Nether- lands) and longwave radiation (Eppley Pyrgeometers, Eppley laboratory Inc., Model Precision Infrared Radiometers) were measured. As backup of these radiation balance measurements the net radiation was measured (Campbell Scientific, Q10). All radiometers were installed at a height of $2.5 \mathrm{~m}$ (except incoming long wave radiation at $1.6 \mathrm{~m}$ height). Wind direction was monitored with a wind vane (Campbell Scientific Ltd, W200P) on top of the tower (4.6 m height) and wind speed with cup anemometers (Vector Instruments model A100M/A100ML) at 3.0 and $2.0 \mathrm{~m}$ height. Soil temperature was measured at various depths $(0.01,0.02,0.04$, $0.06,0.08,0.10,0.15,0.25,0.40$ and $0.60 \mathrm{~m}$ ) by thermistor probes (Campbell Scientific Ltd, model 107). The canopy skin temperature was measured using infrared thermometers (Everest, model 4000 BL). Precipitation was monitored with a tipping bucket rain gauge (Campbell Scientific Ltd, model ARG100), with a resolution of $0.2 \mathrm{~mm}$, which was installed at $1.05 \mathrm{~m}$ above the ground. The instruments were sampled with a data logger (Campbell Scientific, model 23X) every $30 \mathrm{~s}$ ( $2 \mathrm{~s}$ for thermocouple) and the data stored as $30 \mathrm{~min}$ averages and standard deviations.

A quality check was performed during which all outliers and unrealistic values were removed from all eddy covariance data and meteorological data (Table 3). Next, gap filling with $u_{*}$ correction was performed through methods that are similar to Falge et al. (2001), with consideration of both the co-variation of fluxes with meteorological variables and the temporal auto-correlation of the fluxes (Reichstein et al., 2005).

\subsection{Soil flux measurement techniques, data acquisition and processing}

Closed flux chamber measurements of $\mathrm{CH}_{4}$ and $\mathrm{N}_{2} \mathrm{O}$ fluxes were performed using a Photo Acoustic Field Gas-Monitor (type 1312, Innova AirTech Instruments, Ballerup, Denmark) connected with tubes to closed, dark chambers (non- 
Table 4. Water balance components total per year (right) and averaged per day (left).

\begin{tabular}{|c|c|c|c|c|c|c|}
\hline water balance components & $\left(\mathrm{mm} \mathrm{day}^{-1}\right)$ & $\begin{array}{c}\text { daily average } \\
\text { uncertainty }\end{array}$ & $\left(\mathrm{mm} \mathrm{day}^{-1}\right)$ & $\left(\mathrm{m} \mathrm{yr}^{-1}\right)$ & $\begin{array}{l}\text { yearly total } \\
\text { uncertainty }\end{array}$ & $\left(\mathrm{m} \mathrm{yr}^{-1}\right)$ \\
\hline Precipitation & -1.85 & $10 \%$ & 0.19 & -0.676 & $10 \%$ & 0.068 \\
\hline Vertical Flow on Land & 1.86 & & & 0.679 & & \\
\hline Vertical Flow at Ditches & -8.40 & & & -3.065 & & \\
\hline Net Vertical Flow & -0.19 & $20 \%$ & 0.04 & -0.070 & $20 \%$ & 0.014 \\
\hline Discharge & 0.47 & $10 \%$ & 0.05 & 0.173 & $10 \%$ & 0.017 \\
\hline Evaporation (land and water) & 1.81 & $10 \%$ & 0.18 & 0.660 & $10 \%$ & 0.066 \\
\hline Storage & 0.24 & & 0.45 & 0.088 & & 0.165 \\
\hline
\end{tabular}

transparent PVC, $45 \times 45 \times 12$ or $30 \mathrm{~cm}$ ). The Gas-Monitor detection limit and precision is dependent on the "least detected level" value of the optical filter used for a specific gas. Reliable measurements could be made from $1.0 \mathrm{ppm}$ for $\mathrm{CH}_{4}$ and $300 \mathrm{ppb}$ for $\mathrm{N}_{2} \mathrm{O}$ with a precision of $2 \mathrm{ppb}$ and $0.6 \mathrm{ppb}$ respectively.

A fan was installed in the chambers to mix the air and increase the representativeness of the measurements. The software of the gas monitor compensates for cross-interference of $\mathrm{CO}_{2}$ and water vapour. Additionally, to minimize any possible effect of the interference of those gases, the air was filtered before measurement with a Sodalime filter and a silica gel filter respectively (Van Huissteden et al., 2005). $\mathrm{CO}_{2}$ and water vapour concentrations remained constant during the flux measurement procedure when the filters were used. The Sodalime filter was replaced when the Gas-Monitor gas monitor indicated concentrations higher than $100 \mathrm{ppm} \mathrm{CO}_{2}$ while filtering the air for $\mathrm{CO}_{2}$. The silica gel (Riedel-de Haen, Germany) contains moisture indicating pearls and was replaced at least after every ten measurements or when pearls indicated saturation. To prevent vegetation disturbance, chambers with a height of $30 \mathrm{~cm}$ were used. Vegetation was not removed preceding the flux measurements, to maintain the representativeness of the chamber measurements for a larger area. However, when measurements were performed over vegetation higher than $30 \mathrm{~cm}$, it was cut to this size. During each measurement soil temperature and local water table were determined.

On land, at eight fixed locations stainless steel frames with a water-filled gutter were used to seal the chamber from the ambient air during measurement. Six of the locations were positioned in the relatively dry part of the area evenly spread over the various vegetation types. At each of those six locations, fluxes were measured 49 times between January 2004 and December 2006. The two other locations were in the part of the area with saturated soils and were measured 17 times each. On the ditch water surface, measurements were made at two locations. For this purpose a rectangular floater was used allowing the chamber to rest on the water. Between January 2006 and December 2006, fluxes were measured 17 times on the ditch at the east side and 14 times at the ditch at the west side of the research area. At all sites the flux measurements were performed approximately once every 4 weeks during winter and once every two weeks during summer.

For each flux measurement five concentration measurements were performed at two-minute intervals. The series of concentration measurements made with the flux chamber technique were calculated into fluxes by determining linear regression lines from the concentration changes over time. Air pressure and temperature from the moment of measuring were taken into account in the calculations. Data were checked for outliers that may result from instrument error, chamber leakage or irregular ebullition events. Fluxes of $\mathrm{N}_{2} \mathrm{O}$ appeared to be negligible small with respect to the GHG balance (between -0.1 and $0.1 \mathrm{mg} \mathrm{m}^{-2} \mathrm{hr}^{-1}$ ) and contained measurement errors of more than $70 \%$ on average. Therefore, the $\mathrm{N}_{2} \mathrm{O}$ flux measurements were not considered in further analyses.

\subsection{Vegetation and soil analyses}

The vegetation was surveyed in 2005 and consisted of vegetation classification and air photo analysis. Biomass was determined in May and October 2005 by harvesting in $40 \times 40 \mathrm{~cm}$ squares and seperating dead and living biomass. Soil analysis was performed on samples obtained by $0.12 \mathrm{dm}^{3}$ sample rings for undisturbed sampling. Permeability was determined with a permeameter using the falling head method. The $\mathrm{C} / \mathrm{N}$-ratios of these samples were determined with a Flash 122, while the organic matter content was determined with thermogravimetry. Using an automatic oven (Leco TGA-601), samples were stepwise heated up to $1000^{\circ} \mathrm{C}$ in an oxygen atmosphere, with heating plateaus at $105^{\circ} \mathrm{C}$ and $500^{\circ} \mathrm{C}$. 


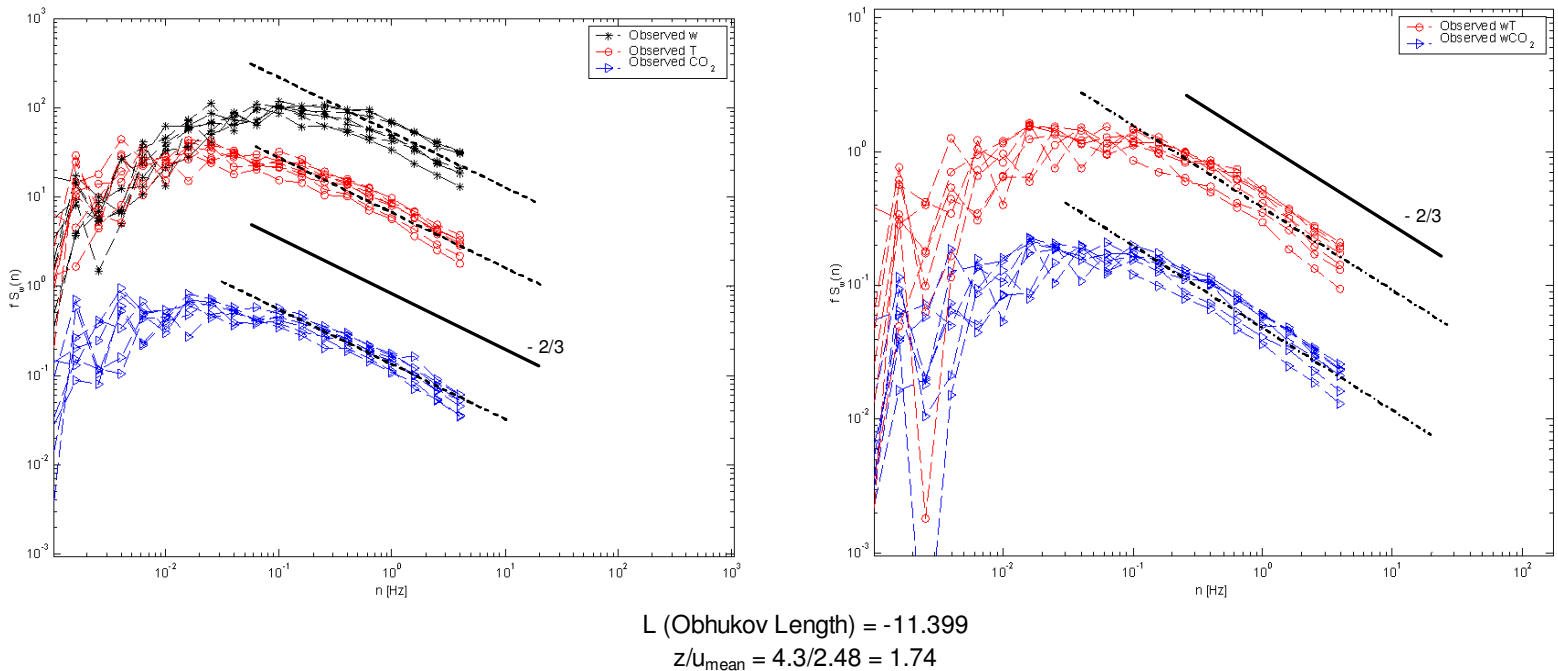

Fig. 2. Power-spectra of $w, T$ and $\mathrm{CO}_{2}$-concentration (left) and co-spectra of $w^{\prime} T^{\prime}$ and $w^{\prime} \mathrm{CO}_{2}^{\prime}$ (right) for $10 \mathrm{~Hz}$ eddy covariance data of seven half hours in spring 2005. Data are averaged per half hour.

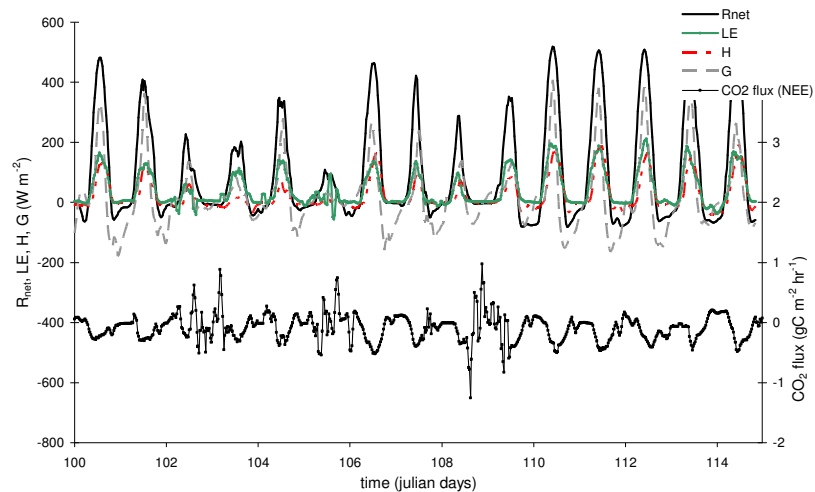

Fig. 3. Diurnal pattern of energy balance components net radiation, latent heat, sensible heat and ground heat flux and $\mathrm{CO}_{2}$ flux for seven days in spring 2005.

\section{Results}

\subsection{Water balance}

Water entered the system either as precipitation or as seepaging groundwater, mainly in the ditches. Losses consisted of evapotranspiration and runoff over a fixed weir as well as some infiltration of soil water to the Pleistocene sand aquifer underlying the clayey peat. Since the permeability of the peat layer was very low $\left(0.023 \mathrm{~m} \mathrm{day}^{-1}\right)$, we assume that a significant part of the vertical flow in the soil water actually follows sub-horizontal flow paths. Using the precipitation data, water levels and evapotranspiration data (observed by the eddy covariance system) from 25 May 2005 to 25 May 2006, the storage of water per hectare in the soil of the Horstermeer was calculated using the following water balance equation:

$P-V F D-V F L-Q-E T=$ Storage

where:

$P=$ precipitation;

$V F D=$ vertical flow in ditches;

$V F L=$ vertical flow on land; $Q=$ discharge;

$E T=$ evapotranspiration.

The annual precipitation was nearly equalled by the evapotranspiration (Table 4), but was low compared to the average annual rainfall of $775-800 \mathrm{~mm}$ in the area (source: KNMI, Royal Dutch Meteorological Institute). The runoff from the research site consisted only of discharge over the weir and was low. Seepage was the dominant vertical flow in the ditches, while on land infiltration of soil water prevails. Taking into account the relative surface area of land and ditches, the net vertical flow over the whole area was $-0.070 \pm 0.014 \mathrm{~m} \mathrm{yr}^{-1}$ (seepage).

\subsection{Performance of the eddy covariance set-up}

Spectral analysis of the fluctuations of the vertical wind speed $(w)$, air temperature $(T)$ and $\mathrm{CO}_{2}$ in the atmosphere associated with turbulent transport provide a useful tool for assessing the reliability of flux measurements (Stull, 1988; Kaimal and Finnigan, 1994). We determined power-spectra of the wind, temperature and $\mathrm{CO}_{2}$ concentration as well as co-spectra of temperature fluxes and $\mathrm{CO}_{2}$ fluxes (Fig. 2). $10 \mathrm{~Hz}$ eddy covariance data of seven 30 min periods in spring 2005 were used for this purpose. The power-spectra and cospectra were binned and plotted as a function of frequency at $\log -\log$ scale. Power-spectra for $w, T$ and $\mathrm{CO}_{2}$ have corresponding slopes showing a proportionality of $-2 / 3$, which 

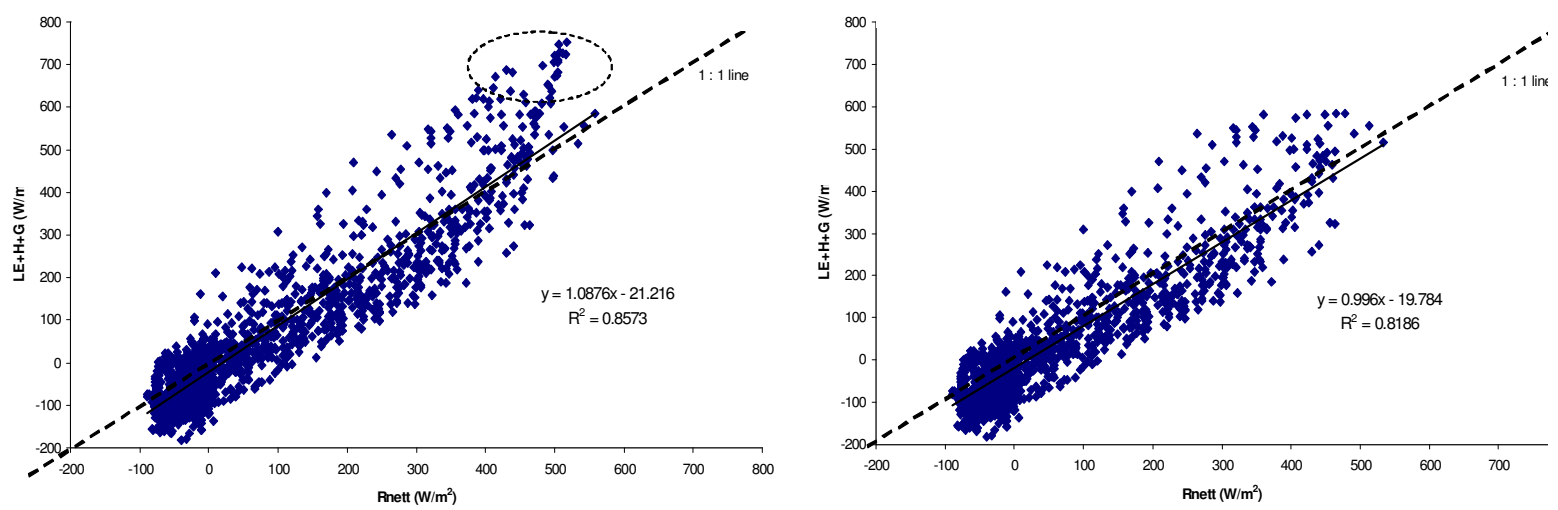

Fig. 4. Energy balance closure for daytime periods over a three week period during the spring of 2005 with 1:1 line and linear relation. In the left plot a circle is drawn around the outlying mid-day data points. In the right plot mid-day measurements are removed.

is in agreement with the power law in the inertial sub-range (Eugster and Senn, 1995). Under ideal circumstances the shapes of the $w^{\prime} \mathrm{CO}_{2}{ }^{\prime}$ and $w^{\prime} T^{\prime}$ co-spectra should be similar. Here the co-spectra showed comparable shapes and have corresponding slopes with a proportionality of $-2 / 3$. The power spectrum of the $\mathrm{CO}_{2}$ time series, the co-spectrum of vertical wind and $\mathrm{CO}_{2}$ as well as the co-spectrum of vertical wind and air temperature indicated that the eddy covariance set-up recorded nearly all the fluctuations in $\mathrm{CO}_{2}$ associated with turbulent transport (Goulden et al., 1996), and that the measurements were taken in a well established surface layer.

In the energy balance, the ground heat flux $(G)$ in the clayey peat soil was relatively important compared to the latent and sensible heat fluxes ( $L E$ and $H$ respectively) and amounted to over half of the energy in the net radiation $\left(R_{\text {net }}\right)$ (Fig. 3). The closure of the energy balance was good (Fig. 4), but the values of the sum of $L E, H$ and $G$ were relatively high at sunny days around noon, resulting in a regression line with a slope of more than 1 . These high values of the sum of $L E, H$ and $G$ at sunny hours around noon were mainly the result of extremely high apparent $G$. These high $G$ values were caused by erroneous measurements of the upper soil heat sensors due to overheating during periods with a lot of sunlight. When these data points with erroneous $G$ values were removed from the data set, the regression line had a slope of 0.996 and an $R^{2}$ of 0.82 . This implied that the quality of the data from the eddy covariance set-up was very good (Lloyd et al., 1997).

The uncertainty of NEE was based on the percentage of data gaps in the eddy covariance data after performing the quality check and $u_{*}$-correction. KNMI air temperature data from De Bilt were used to support the gap filling method when necessary. The distance between the site and the KNMI observation is $20 \mathrm{~km}$. Uncertainties resulting from the gapfilling procedure are directly proportional to the amount of gaps filled over the measurement period (Falge et al., 2001). We introduced the maximum error in NEE of $0.675 \mathrm{~g} \mathrm{C} \mathrm{m}^{-2}$ per percentage gap-filled per year. The total amount of data gaps was $36.72 \%$ for $2004,26.37 \%$ for 2005 and $29.70 \%$ for 2006, resulting in a maximum error of $25 \mathrm{~g} \mathrm{C} \mathrm{m}^{-2} \mathrm{yr}^{-1}$, $18 \mathrm{~g} \mathrm{C} \mathrm{m}^{-2} \mathrm{yr}^{-1}$ and $20 \mathrm{~g} \mathrm{C} \mathrm{m}^{-2} \mathrm{yr}^{-1}$ respectively. According to Van der Molen et al. (personal communication, 2007) ${ }^{1}$ the error introduced by the calculation routines was $13 \%$ of the total annual NEE.

\subsection{Carbon dioxide fluxes}

The net $\mathrm{CO}_{2}$ flux followed a daily pattern with periods of net $\mathrm{CO}_{2}$ uptake during daytime and respiration during night time (Fig. 3). In Fig. 5 the $\mathrm{CO}_{2}$ fluxes are shown as daily fluxes in $\mathrm{g} \mathrm{C} \mathrm{m}^{-2}$ day $^{-1}$ as well as the cumulative $\mathrm{CO}_{2}$ flux in $\mathrm{g} \mathrm{C} \mathrm{m}^{-2} \mathrm{yr}^{-1}$ over the year. The growing season in 2004 (period where NEE is negative) lasted from 7 April to 14 October and had a NEE of $-543 \mathrm{~g} \mathrm{C} \mathrm{m}^{-2}$. The NEE for 2004 was cumulated, resulting in an annual NEE of $-446 \pm 83 \mathrm{~g} \mathrm{C} \mathrm{m}^{-2} \mathrm{yr}^{-1}$. The growing season in 2005 lasted from 25 March to 8 September and had a NEE - $327 \mathrm{~g} \mathrm{C} \mathrm{m}^{-2}$, while the annual NEE amounted $-311 \pm 58 \mathrm{~g} \mathrm{C} \mathrm{m}^{-2} \mathrm{yr}^{-1}$. The growing season in 2006 lasted from 25 April to 2 September and had a NEE of $-283 \mathrm{~g} \mathrm{C} \mathrm{m}^{-2}$, while the annual NEE amounted $-232 \pm 58 \mathrm{~g} \mathrm{C} \mathrm{m}^{-2} \mathrm{yr}^{-1}$.

Net ecosystem exchange was determined directly from the eddy covariance $\mathrm{CO}_{2}$ flux measurements and was considered to be the sum of the gross ecosystem production (GEP) and $\mathrm{R}_{\mathrm{eco}}$ (the sum of heterotrophic and autotrophic respiration). $\mathrm{R}_{\mathrm{eco}}$ could be expressed by its physical exponential relation with soil temperature (Lloyd and Taylor, 1994; Van't Hoff, 1898). For the Horstermeer site the exponential relation for $\mathrm{R}_{\text {eco }}$ was determined empirically using nocturnal NEE values (incoming shortwave radiation $\mathrm{SW}_{\text {in }}<20 \mathrm{~W} \mathrm{~m}^{-2}$ ) assuming photosynthesis was absent and the NEE consist only of $R_{\text {eco }}$ (Fig. 6, Eq. 2).

\footnotetext{
${ }^{1}$ Van der Molen, M. K., Dolman, A. J., Marchesini, L. B., et al.: The carbon balance of the Boreal Eurasia consolidated with eddy covariance observations, personal communiction, 2007.
} 
Table 5. NEE, GEP and $\mathrm{R}_{\mathrm{eco}}$ for growing seasons, non-growing seasons and whole years over 2004, 2005 and 2006.

\begin{tabular}{lccccccccc}
\hline & $\begin{array}{c}\text { Growing } \\
\text { Season 2004 }\end{array}$ & $\begin{array}{c}\text { Non-Growing } \\
\text { Season 2004 }\end{array}$ & $\begin{array}{c}\text { Year } \\
2004\end{array}$ & $\begin{array}{c}\text { Growing } \\
\text { Season 2005 }\end{array}$ & $\begin{array}{c}\text { Non-Growing } \\
\text { Season 2005 }\end{array}$ & $\begin{array}{c}\text { Year } \\
2005\end{array}$ & $\begin{array}{c}\text { Growing } \\
\text { Season 2006 }\end{array}$ & $\begin{array}{c}\text { Non-Growing } \\
\text { Season 2006 }\end{array}$ & $\begin{array}{c}\text { Year } \\
2006\end{array}$ \\
\hline Length of period & 192 & 174 & 366 & 168 & 197 & 365 & 129 & 236 \\
DOY of period & $96-288$ & $288-96$ & $1-366$ & $83-251$ & $251-83$ & $1-365$ & $115-244$ & $244-115$ & $1-365$ \\
NEE $\left(\mathrm{gC} \mathrm{m}^{-2} \mathrm{yr}^{-1}\right)$ & -543 & 97 & -446 & -327 & 16 & -311 & -283 & 51 & -232 \\
GEP $\left(\mathrm{gC} \mathrm{m}^{-2} \mathrm{yr}^{-1}\right)$ & -1213 & -101 & -1314 & -877 & -300 & -1177 & -804 & -352 & -1156 \\
$\mathrm{R}_{\mathrm{eco}}\left(\mathrm{gC} \mathrm{m}^{-2} \mathrm{yr}^{-1}\right)$ & 670 & 199 & 869 & 550 & 316 & 866 & 521 & 403 & 924 \\
\hline
\end{tabular}

Table 6. Regression analyses of relations between $\mathrm{CH}_{4}$ fluxes, soil temperature and water level for relatively dry land, saturated land and ditches. From left to right the correlation coefficients, amount of samples $(n)$ goodness-of-fit of the correlation $\left(R^{2}\right), F$-test with significance ( $p$-value) and variance error as well as the regression equation for $\mathrm{CH}_{4}$ with soil temperature are shown.

\begin{tabular}{|c|c|c|c|c|c|c|c|c|c|}
\hline & \multicolumn{3}{|c|}{ correlation coefficients } & \multicolumn{5}{|c|}{ statistical parameters } & \multirow[t]{2}{*}{ Regression equations } \\
\hline & $\ln \left(\mathrm{CH}_{4}\right)-T_{\text {soil }}$ & $\ln \left(\mathrm{CH}_{4}\right)$-soil wll & $T_{\text {soil }}$-soil wll & $n$ & $R^{2}$ & $F$-test & $p$-value & variance error & \\
\hline dry land & 0.294 & -0.132 & -0.663 & 294 & 0.086 & 14.273 & 0.000 & 1.845 & $\mathrm{CH}_{4}=\exp \left(-0.261+0.060 * T_{\text {soil }}\right)$ \\
\hline saturated land & 0.493 & -0.362 & -0.671 & 34 & 0.243 & 3.210 & 0.103 & 0.292 & $\mathrm{CH}_{4}=\exp \left(2.205+0.045^{*} T_{\text {soil }}\right)$ \\
\hline ditches & 0.676 & 0.000 & 0.000 & 31 & 0.457 & 9.261 & 0.011 & 0.292 & $\mathrm{CH}_{4}=\exp \left(0.767+0.079 * T_{\text {soil }}\right)$ \\
\hline
\end{tabular}

$\mathrm{R}_{\mathrm{eco}}=0.0077 \times e^{(0.1415 \times T \text { soil })}$

(error variance $=0.77$ and $R^{2}=0.5137$ )

The results of the flux partitioning of NEE in $\mathrm{R}_{\mathrm{eco}}$ and GEP are listed in Table 5 and plotted over the year (Fig. 5). Another attempt to partition the NEE fluxes of 2005 was made by using the model of Reichstein et al. (2005). This model uses air temperature to partition the data and resulted in a partitioning of $-311 \mathrm{~g} \mathrm{C} \mathrm{m}^{-2} \mathrm{yr}^{-1} \mathrm{NEE}$ in a GEP of $-1135 \mathrm{~g} \mathrm{C} \mathrm{m}^{-2} \mathrm{yr}^{-1}$ and $\mathrm{R}_{\mathrm{eco}}$ of $823 \mathrm{~g} \mathrm{C} \mathrm{m}^{-2} \mathrm{yr}^{-1}$. The difference between the results of the two methods for flux partitioning was small. Since the first method (using nocturnal NEE) uses soil temperature instead of air temperature we consider this as a more physically based method as soil temperature was more closely related to $\mathrm{R}_{\mathrm{eco}}$.

\subsection{Methane fluxes}

Significantly different fluxes were measured at the three land elements relatively dry land, saturated land and water surfaces and therefore they were considered separately in further analyses and data processing. Measured $\mathrm{CH}_{4}$ fluxes observed at the relatively dry land varied from -1.1 to $15.2 \mathrm{mg} \mathrm{C} \mathrm{m}^{-2} \mathrm{hr}^{-1}$ with an average of $1.7 \pm 0.2 \mathrm{mg} \mathrm{C} \mathrm{m}^{-2} \mathrm{hr}^{-1}$, while fluxes observed at saturated land varied from -8.4 to $48.5 \mathrm{mg} \mathrm{C} \mathrm{m}^{-2} \mathrm{hr}^{-1}$ with a average of $13.8 \pm 2.2 \mathrm{mg} \mathrm{C} \mathrm{m}^{-2} \mathrm{hr}^{-1}$. $\mathrm{CH}_{4}$ fluxes from the ditches varied from 0.4 to $18.4 \mathrm{mg} \mathrm{C} \mathrm{m}^{-2} \mathrm{hr}^{-1}$ with an average of $6.8 \pm 0.9 \mathrm{mg} \mathrm{C} \mathrm{m}^{-2} \mathrm{hr}^{-1}$ (Fig. 7). The $\mathrm{CH}_{4}$ fluxes of the saturated land were significantly highest and fluxes from all sur- face types showed a seasonal trend over the year with the highest fluxes in late spring, summer and early autumn.

In previous studies relations between soil temperature and $\mathrm{CH}_{4}$ flux and between soil water level and $\mathrm{CH}_{4}$ flux were found (Aerts and Toet, 1997; Fiedler and Sommer, 2000; Smith et al., 2003). Statistical analysis of the data showed that in our case the temporal variation of the $\mathrm{CH}_{4}$ fluxes was significantly correlated with soil temperature, but barely correlated with water level (Table 6) while water level is significantly correlated with soil temperature. This phenomenon was encountered earlier by Wagner et al. (1999) in a marshland. We assume that the lack of correlation between $\mathrm{CH}_{4}$ flux and soil water level is caused by the soil characteristics at the Horstermeer research site. Peaty and clayey soils often contain anaerobic areas above the water level. In those zones in the soil methanogenesis occurs and $\mathrm{CH}_{4}$ fluxes at the surface can be higher than expected. As a consequence of the low correlation with $\mathrm{CH}_{4}$ fluxes, soil water levels were not taken into account in the regression analyses of the $\mathrm{CH}_{4}$ fluxes. The following exponential regression equations describe the $\mathrm{CH}_{4}$ flux for the three land elements:

Dry land:

$\mathrm{CH}_{4}$ flux $=e^{(-0.261+0.060 \times T \text { soil })}$

(error variance $=1.84$ and $R^{2}=0.086$ )

Saturated land:

$\mathrm{CH}_{4}$ flux $=e^{(2.205+0.045 \times T \text { soil })}$

(error variance $=0.29$ and $R^{2}=0.243$ ) 

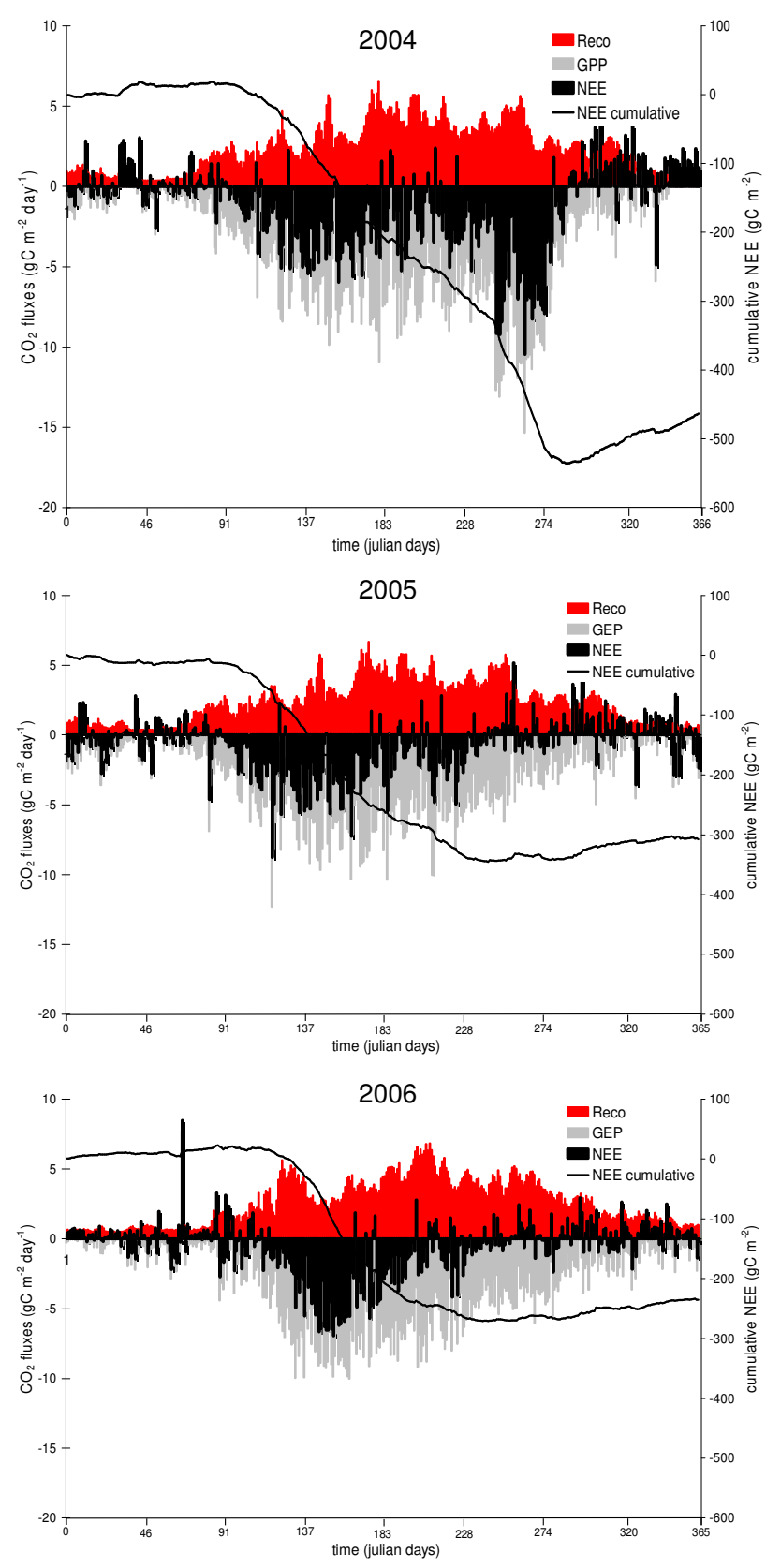

Fig. 5. Daily NEE, GEP, $R_{\mathrm{eco}}$ and cumulative NEE over the year for 2004 (upper graph), 2005 (middle graph) and 2006 (bottom graph).

Ditches:

$\mathrm{CH}_{4}$ flux $=e^{(0.767+0.079 \times T \text { soil })}$

(error variance $=0.29$ and $R^{2}=0.457$ )

Using these regression equations and continuous soil temperature data, the annual $\mathrm{CH}_{4}$ flux for the three land elements could be determined (Table 7 and Fig. 8). The $\mathrm{CH}_{4}$ fluxes of the dry land have a high variance error and were low compared to the fluxes from the ditches and the saturated

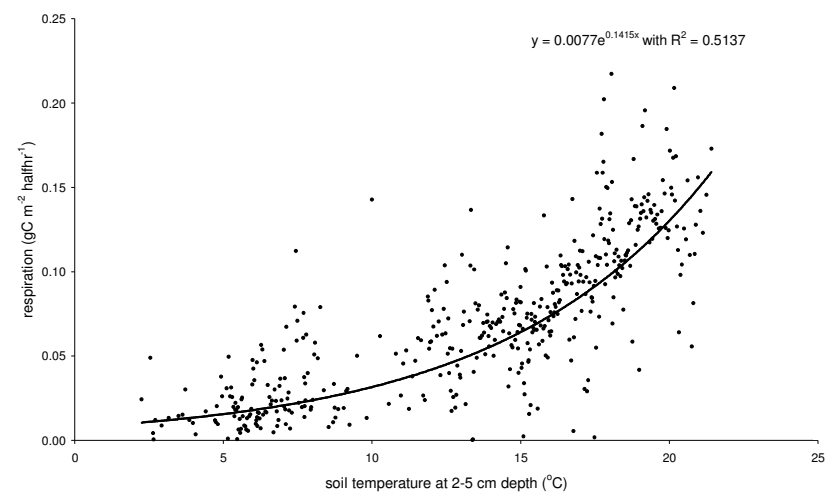

Fig. 6. Relation between soil temperature and respiration using nocturnal $\mathrm{CO}_{2}$ fluxes with the exponential best fit line and its regression equation.
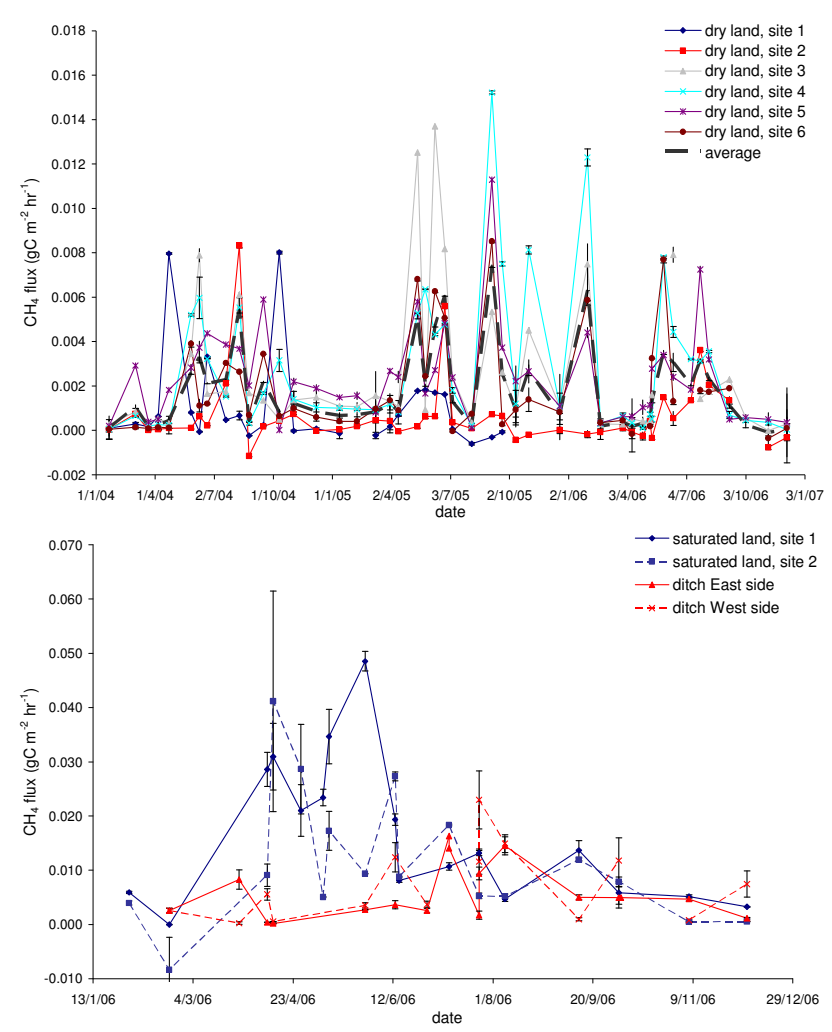

Fig. 7. Measured $\mathrm{CH}_{4}$ fluxes at the Horstermeer site over the period 2004 to 2006 for the relatively dry land (above) and over 2006 for the saturated land and the ditches (below).

land. Since uncertainties of the regression equations were very large (Table 6), annual totals were also determined using linear interpolation of the data points. Uncertainties were estimated by determination of the total variance between the annual totals of the different flux sites. The two methods did not differ significantly both in annual totals and uncertainties (Table 7). 
Table 7. Annual totals of $\mathrm{CH}_{4}$ emission from the relatively dry land, the saturated land and the ditches as well as the weighted average determined by regression equations and by linear interpolation.

\begin{tabular}{lccccc}
\hline & \multicolumn{2}{c}{ results regression equations } & \multicolumn{2}{c}{ results linear interpolation } \\
\hline land type & year & $\begin{array}{c}\mathrm{CH}_{4} \text { flux } \\
\left(\mathrm{gC} \mathrm{m}^{-2} \mathrm{yr}^{-1}\right)\end{array}$ & $\begin{array}{c}\text { uncertainty } \\
\left(\mathrm{gC} \mathrm{m}^{-2} \mathrm{yr}^{-1}\right)\end{array}$ & $\begin{array}{c}\mathrm{CH}_{4} \text { flux } \\
\left(\mathrm{gC} \mathrm{m}^{-2} \mathrm{yr}^{-1}\right)\end{array}$ & $\begin{array}{c}\text { uncertainty } \\
\left(\mathrm{gC} \mathrm{m}^{-2} \mathrm{yr}^{-1}\right)\end{array}$ \\
\hline relatively dry land & 2005 & 10.40 & 19.20 & 18.99 & 15.50 \\
relatively dry land & 2006 & 10.80 & 19.80 & 15.26 & 11.70 \\
saturated land & 2005 & 101.30 & 29.60 & - & - \\
saturated land & 2006 & 104.00 & 30.40 & 87.63 & - \\
ditches & 2005 & 37.30 & 10.40 & - & - \\
ditches & 2006 & 39.05 & 11.40 & 52.45 & 8.50 \\
weighted average & 2005 & 31.27 & 20.40 & & 13.14 \\
weighted average & 2006 & 32.27 & 21.08 & 33.45 & \\
\hline
\end{tabular}

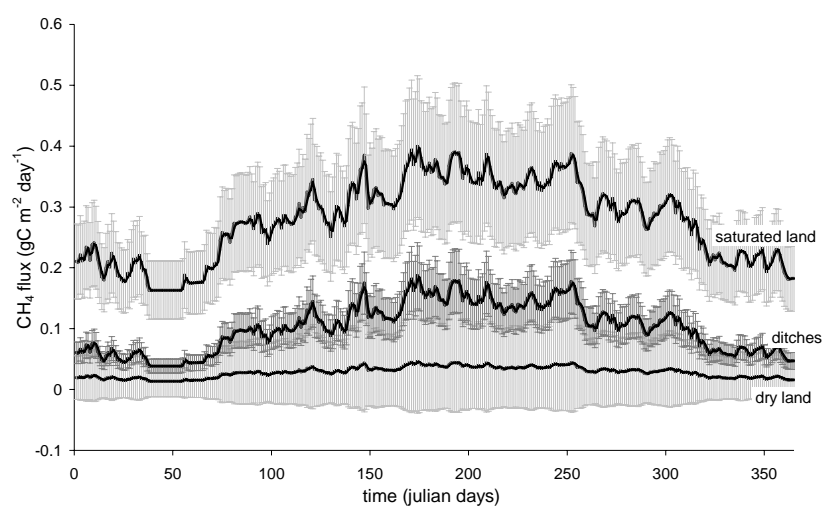

Fig. 8. Modelled daily $\mathrm{CH}_{4}$ fluxes for relatively dry land, saturated land and ditches over 2005. Error-bars indicate the variance error from the regression analysis.

\subsection{Fluxes of Total Carbon and dissolved $\mathrm{CH}_{4}$ through wa- ter}

The analyses of soil water, ground water and ditch water for $\mathrm{TC}$ and dissolved $\mathrm{CH}_{4}$ show that highest concentrations were found in the soil water, while the ground water and ditch water contained relatively little TC and dissolved $\mathrm{CH}_{4}$ (Tables 8 and 9). Theoretically, the maximum concentration of dissolved $\mathrm{CH}_{4}$ in water under the conditions of the soil in the Horstermeerpolder is $26 \mathrm{~g} \mathrm{C} \mathrm{m}^{-3}$ $\left(10^{\circ} \mathrm{C} ; 2 \mathrm{~m}\right.$ deep). Higher concentrations of $\mathrm{CH}_{4}$ in the soil water cause a gas pressure that is higher than the hydrostatic pressure and therefore gas bubbles will form in the soil which move upward and will be emitted as gas flux at the soil surface (Obdam et al., 2001; Strack et al., 2006). In further calculations this maximum concentration of $26 \mathrm{~g} \mathrm{C} \mathrm{m}^{-3}$ for soil water was used. The fluxes of TC and dissolved $\mathrm{CH}_{4}$ by water transport were calculated by multiplying the $\mathrm{TC}$ and dissolved $\mathrm{CH}_{4}$ concentrations with the corresponding water volumes from the water balance. Over the year a net amount of $16.069 \pm 4.754 \mathrm{~g} \mathrm{C} \mathrm{m}^{-2} \mathrm{yr}^{-1}$ was transported out of the research site as TC, while a net amount of $1.182 \pm 0.475 \mathrm{~g} \mathrm{C} \mathrm{m}^{-2} \mathrm{yr}^{-1}$ was transported out of the research area as dissolved $\mathrm{CH}_{4}$. This transport mainly took place by infiltration to the groundwater and discharge of surface water.

\subsection{A full Greenhouse Gas balance}

All incoming and outgoing carbon fluxes through air and water at the measurement site were available for 2005 and were determined per square meter peat meadow per year. As mentioned before, the surface of the research area consists for $10 \%$ of ditches, for $20 \%$ of land that is saturated year-round and for $70 \%$ of land with a fluctuating water table and aerated top-layer. This ratio was taken into account while calculating the annual fluxes of $\mathrm{CH}_{4}$. Fluxes were considered in amounts of carbon and also converted to their GWP.

The exchange of GHG's through air has a direct effect on the GHG budget of the local atmosphere. The carbon fluxes with water as transport medium form sources and sinks as well, but when and where they will turn into gaseous state and affect the atmospheric GHG balance is unknown. Nevertheless the fluxes through water have an indirect effect on the carbon balance by transporting carbon from the system with the runoff and by transporting carbon into or out of the system via the underground, affecting the availability of carbon in the system for exchange with atmosphere. In order to make this distinction between direct and indirect effects on the carbon balance, the direct net carbon flux with atmosphere was considered separately (Table 10), in addition to the total carbon balance where atmosphere and water were both taken into account.

From the total incoming carbon, $-1177 \pm 905 \mathrm{gC}$ $\mathrm{m}^{-2} \mathrm{yr}^{-1}$ (99.5\% of all $\mathrm{CO}_{2}$-equiv.) entered the system due to accumulation of plant material (GEP), while 
Table 8. Results of the water analyses for Total Carbon (TC) in the water, water fluxes over the year and annual fluxes of TC transported by water.

\begin{tabular}{|c|c|c|c|c|c|c|c|}
\hline & & $\begin{array}{l}\text { in water } \\
\left.\mathrm{g} \mathrm{m}^{-3}\right)\end{array}$ & uncertainty & $\begin{array}{l}\text { water flux } \\
\left(\mathrm{m} \mathrm{yr}^{-1}\right)\end{array}$ & uncertainty & $\begin{array}{c}\text { total TC } \\
\left(\mathrm{gC} \mathrm{m}^{-2} \mathrm{yr}^{-1}\right)\end{array}$ & $\begin{array}{c}\text { uncertainty } \\
\left(\mathrm{gC} \mathrm{m}^{-2} \mathrm{yr}^{-1}\right)\end{array}$ \\
\hline seepage in ditch & 41.14 & in ground water & $6 \%$ & -0.062 & $20 \%$ & -2.546 & 0.662 \\
\hline infiltration in ditch & 53.50 & in ditch water & $6 \%$ & 0.001 & $20 \%$ & 0.031 & 0.008 \\
\hline seepage on land & 41.14 & in ground water & $6 \%$ & -0.008 & $20 \%$ & -0.314 & 0.082 \\
\hline infiltration on land & 157.90 & in soil water & $6 \%$ & 0.062 & $20 \%$ & 9.786 & 2.544 \\
\hline discharge surface water & 53.50 & in ditch water & $6 \%$ & 0.170 & $10 \%$ & 9.111 & 1.458 \\
\hline \multicolumn{3}{|c|}{ net yearly flux of TC in water } & & & & 16.069 & 4.754 \\
\hline
\end{tabular}

Table 9. Results of the water analyses for dissolved $\mathrm{CH}_{4}$ in the water, water fluxes over the year and total fluxes of dissolved $\mathrm{CH}_{4}$ transported by water.

\begin{tabular}{|c|c|c|c|c|c|c|c|}
\hline & \multicolumn{2}{|c|}{$\begin{array}{l}\text { dissolved } \mathrm{CH}_{4} \text { in water } \\
\qquad\left(\mathrm{gC} \mathrm{m}^{-3}\right)\end{array}$} & \multirow{2}{*}{$\begin{array}{c}\text { uncertainty } \\
13 \%\end{array}$} & \multirow{2}{*}{$\begin{array}{c}\begin{array}{c}\text { water flux } \\
\left(\mathrm{m} \mathrm{yr}^{-1}\right)\end{array} \\
-0.062\end{array}$} & \multirow{2}{*}{$\begin{array}{c}\text { uncertainty } \\
20 \%\end{array}$} & \multirow{2}{*}{$\begin{array}{c}\text { total diss. } \mathrm{CH}_{4} \\
\left(\mathrm{gC} \mathrm{m}^{-2} \mathrm{yr}^{-1}\right) \\
-0.400\end{array}$} & \multirow{2}{*}{$\frac{\begin{array}{c}\text { uncertainty } \\
\left(\mathrm{gC} \mathrm{m}^{-2} \mathrm{yr}^{-1}\right)\end{array}}{0.132}$} \\
\hline seepage in ditch & 6.47 & in ground water & & & & & \\
\hline infiltration in ditch & 2.93 & in ditch water & $13 \%$ & 0.001 & $20 \%$ & 0.002 & 0.001 \\
\hline seepage on land & 6.47 & in ground water & $13 \%$ & -0.008 & $20 \%$ & -0.049 & 0.016 \\
\hline infiltration on land & 26 (measured 66) & in soil water & $0 \%$ & 0.062 & $20 \%$ & 1.627 & 0.325 \\
\hline discharge surface water & 0.02 & in ditch water & $13 \%$ & 0.170 & $10 \%$ & 0.003 & 0.001 \\
\hline \multicolumn{3}{|c|}{ net yearly flux of dissolved $\mathrm{CH}_{4}$} & & & & 1.182 & 0.475 \\
\hline
\end{tabular}

$-3.31 \pm 0.80 \mathrm{~g} \mathrm{C} \mathrm{m}^{-2} \mathrm{yr}^{-1}$ ( $0.5 \%$ of all $\mathrm{CO}_{2}$-equivalents) entered the system with groundwater seepage. From the total emitted carbon $866 \pm 666 \mathrm{~g} \mathrm{C} \mathrm{m}^{-2} \mathrm{yr}^{-1} \quad(74.4 \%$ of all $\mathrm{CO}_{2}$-equiv.) left the system through $\mathrm{R}_{\mathrm{eco}}$, $31.27 \pm 20.43 \mathrm{~g} \mathrm{C} \mathrm{m}^{-2} \mathrm{yr}^{-1} \quad\left(23.2 \%\right.$ of all $\mathrm{CO}_{2}$-equiv. $)$ through emission of $\mathrm{CH}_{4}$ gas, $11.45 \pm 2.90 \mathrm{~g} \mathrm{C} \mathrm{m}^{-2} \mathrm{yr}^{-1}$ (2.0\% of all $\mathrm{CO}_{2}$-equivalents) through infiltration of soil- and ditchwater to deeper aquifers and $9.11 \pm 1.40 \mathrm{~g} \mathrm{C} \mathrm{m}^{-2} \mathrm{yr}^{-1}$ ( $0.8 \%$ of all $\mathrm{CO}_{2}$-equiv.) through discharging ditch water.

When concerning only fluxes with the atmosphere the area was a considerable carbon sink of $-280 \pm 78 \mathrm{~g} \mathrm{C} \mathrm{m}^{-2} \mathrm{yr}^{-1}$, while it was a smaller GHG sink given as $\mathrm{CO}_{2}$-equiv. of $-182 \mathrm{~g} \mathrm{~m}^{-2} \mathrm{yr}^{-1}$ (based on a 100-year time scale) due to the greater GWP of $\mathrm{CH}_{4}$. When fluxes through water were added to the balance, the area was a carbon sink of $-262 \pm 84 \mathrm{~g} \mathrm{C} \mathrm{m}^{-2} \mathrm{yr}^{-1}$, and only a small net GHG sink given as $\mathrm{CO}_{2}$-equiv. of $-86 \mathrm{~g} \mathrm{~m}^{-2} \mathrm{yr}^{-1}$ when considered as GWP (Table 10).

\section{Discussion and conclusions}

These results show that, with considerable experimental effort, it is possible to estimate a full GHG balance and its uncertainties for a specific area by measuring fluxes of $\mathrm{CO}_{2}$, $\mathrm{CH}_{4}$ and $\mathrm{N}_{2} \mathrm{O}$ simultaneously, while also paying attention to fluxes of TC and dissolved methane trough water and taking into account the different GWP's.
The eddy covariance system performed well, as shown by the power-spectra and co-spectra as well as by the closure of the energy balance, and we can put confidence in those results. NEE was satisfactory partitioned in $\mathrm{R}_{\text {eco }}$ and GEP using soil temperature and night time fluxes for 2004, 2005 and 2006 (Table 5 and Fig. 5). NEE of $\mathrm{CO}_{2}$ at the Horstermeer site was high compared to the average NEE of European peat areas which ranges from $-33 \mathrm{~g} \mathrm{C} \mathrm{m}^{-2} \mathrm{yr}^{-1}$ (uptake) for undisturbed peat lands to $188 \mathrm{~g} \mathrm{C} \mathrm{m}^{-2} \mathrm{yr}^{-1}$ (emission) for drained peat lands (Janssens et al., 2005). The high $\mathrm{CO}_{2}$-uptake at the site is the result of a combination of the temperate climate, the high water tables and the lack of management. All plant material formed during the long growing seasons (approximately 200 days) can grow to its full size, resulting in a high GEP and remains in situ after dying. The large amounts of respiring plants resulted in high $\mathrm{R}_{\text {eco }}$ during the summer period, while the anaerobic conditions caused by the high water table are unfavourable for oxidation of organic soils and dead plant material.

$\mathrm{CH}_{4}$ emissions of the area are the net result of methanogenesis in the anaerobic parts of the soil and $\mathrm{CH}_{4}$ oxidation in the aerated parts of the soil. A significant difference between $\mathrm{CH}_{4}$ emissions from relatively dry soils, from saturated soils and from water surfaces was observed (Table 7 and Fig. 7). Especially the $\mathrm{CH}_{4}$ fluxes from the ditch water and from the saturated soil bordering the ditches were high. Here, anaerobic processes, including methanogenesis, 
Table 10. Summary of all carbon fluxes in the research area over 2005. Fluxes are presented in $\mathrm{g} \mathrm{C}, \mathrm{CO}_{2}$-equivalents and percentage of $\mathrm{CO}_{2}$-equivalents.

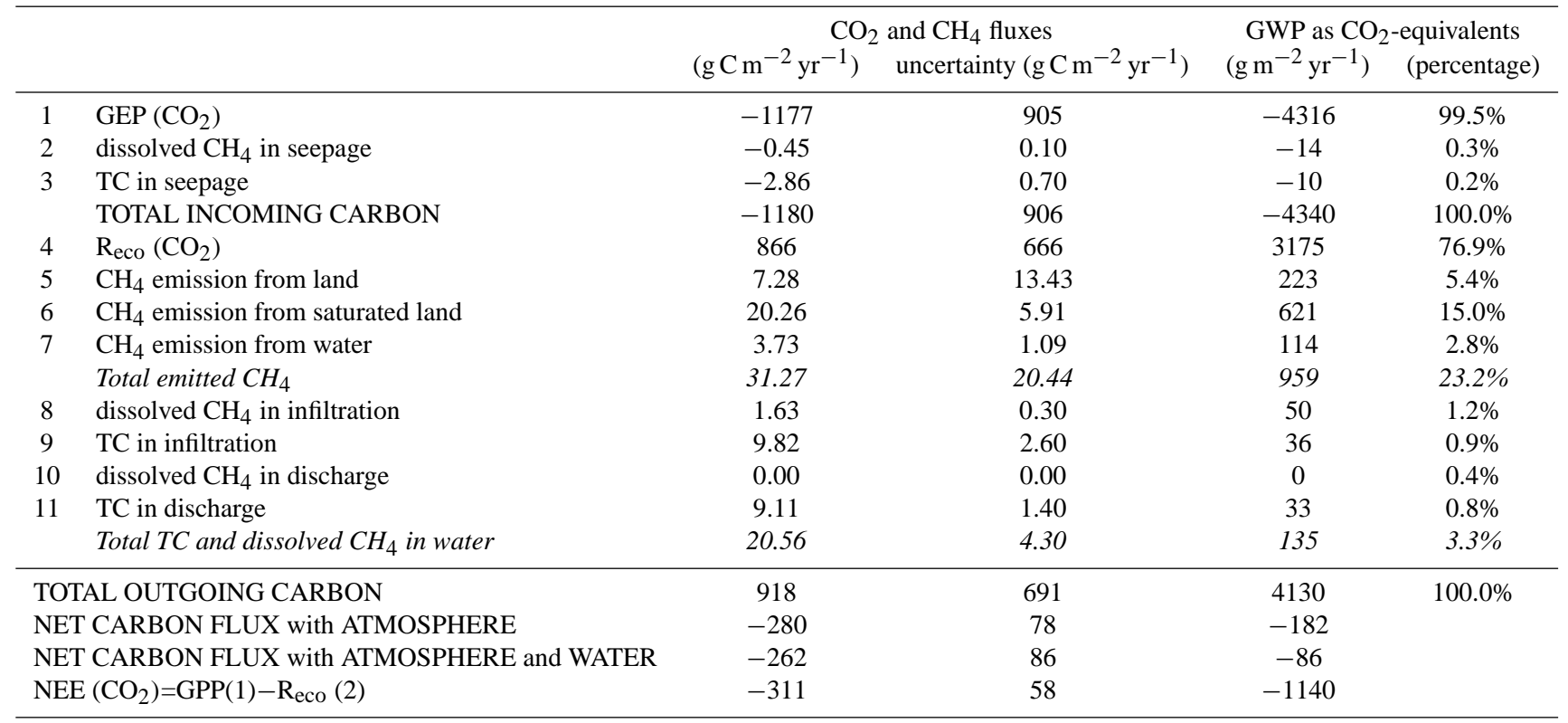

prevail over aerobe processes as result of the water saturated conditions. These observations suggest even higher $\mathrm{CH}_{4}$ emissions in the case of a further rise of the water table. Total weighted fluxes result in a relatively high net $\mathrm{CH}_{4}$ emission $\left(31.27 \pm 20.40 \mathrm{~g} \mathrm{C} \mathrm{m}^{-2} \mathrm{yr}^{-1}\right.$ for 2005 and $32.27 \pm 21.08 \mathrm{~g} \mathrm{C} \mathrm{m}^{-2} \mathrm{yr}^{-1}$ for 2006), even compared to the high average fluxes of $11.4 \mathrm{~g} \mathrm{C} \mathrm{m}^{-2} \mathrm{yr}^{-1}$ from peat lands in Germany and the Netherlands mentioned by Drösler et al. (2007). The Horstermeer site has relatively high soil water levels, and relatively eutrophic soil conditions. In similar conditions elsewhere also high $\mathrm{CH}_{4}$ fluxes have been measured (Fiedler and Sommer, 2000). Additionally, in this research the $\mathrm{CH}_{4}$ fluxes from water surfaces, which increase the average flux from the area, were taken into account. In other research this is often neglected. The emission of $\mathrm{CH}_{4}$ in the Horstermeer polder accounted for $23.2 \%$ of the emitted $\mathrm{CO}_{2}$-equivalents from the peat meadow site. The uncertainty of the up scaling of $\mathrm{CH}_{4}$ based only on soil temperature and water level was, however, high. Further research needs to be performed to improve the understanding of methane fluxes.

The history of the Horstermeer site - a recently re-wetted highly productive peat meadow, with nutrients from fertilization still present in the soil - may have influenced the present high $\mathrm{CH}_{4}$ emission. Nutrient addition may enhance $\mathrm{CH}_{4}$ emission in peat soils (Aerts and Toet, 1997). The more nutrient-poor peat meadow sites of Van den Pol-Van Dasselaar et al. (1999, 1998a, b), with otherwise comparable soils and water table also exhibit lower fluxes than the Horstermeer site. Fiedler and Sommer (2000) report fluxes of similar magnitude as those from the Horstermeer site, from peaty de- pressions with strong agricultural influence in southern Germany. At the site, the ditches and their margins produce the highest fluxes, contributing significantly to the GHG budget. The high methane fluxes from ditches also have been reported from other temperate wetland sites. In particular a nutrient-rich pond margin site produced high $\mathrm{CH}_{4}$ fluxes of up to $77.5 \mathrm{~g} \mathrm{C} \mathrm{m}^{-2} \mathrm{yr}^{-1}$ (Van den Pol-Van Dasselaar et al., 1999; Sundh et al., 2000), being a similar hotspot as the ditch margins at the site. Our results therefore also hint towards management options to reduce $\mathrm{CH}_{4}$ emissions during wetland restoration.

From the undetectable $\mathrm{N}_{2} \mathrm{O}$ fluxes, we can draw two conclusions. First, such small fluxes could not be measured properly with the Innova 1312 Gas-Monitor. Second, the $\mathrm{N}_{2} \mathrm{O}$ fluxes make a negligible contribution to the GHG balance at the site. The formation of $\mathrm{N}_{2} \mathrm{O}$ is normally enhanced by an increase in available mineral nitrogen. Since the site has not been fertilised for more then 10 years, the enhancing effect of fertilisation has probably been diminished and the $\mathrm{N}_{2} \mathrm{O}$ emission is reduced to insignificant proportions.

Water, as transport medium of TC and dissolved $\mathrm{CH}_{4}$, played only a minor role in the balance of GHG's in the area. Only $17.25 \mathrm{~g} \mathrm{C} \mathrm{m}^{-2} \mathrm{yr}^{-1}$ of the total $\mathrm{CO}_{2}$-equivalents were exchanged by transport of water. Although concentrations of $\mathrm{TC}$ and dissolved $\mathrm{CH}_{4}$ in the soil water were high, the impermeable soil prohibits the water to infiltrate quickly. The groundwater, on the other hand, contains relatively small amounts of TC and dissolved $\mathrm{CH}_{4}$. Ditchwater and soil water were therefore barely fed with TC and $\mathrm{CH}_{4}$ through seepaging water. Discharge in this controlled 
area was low compared to other, for example mountainous and uncontrolled areas, where the run off component forms a more important role of washing down of carbon from the system (Hope et al., 2004; Worrall et al., 2005; Ding et al., 2005).

Although the Horstermeer site apparently was a large sink for $\mathrm{CO}_{2}\left(-311 \mathrm{~g} \mathrm{C} \mathrm{m}^{-2} \mathrm{yr}^{-1}\right)$ and was a considerable carbon sink of $-262 \mathrm{~g} \mathrm{C} \mathrm{m}^{-2} \mathrm{yr}^{-1}$ when $\mathrm{CH}_{4}$ fluxes and transport by water are considered, the area was only a small net GHG sink given as $\mathrm{CO}_{2}$-equiv. of $-86 \mathrm{~g} \mathrm{~m}^{-2} \mathrm{yr}^{-1}$ when considered as GWP. Similar results were found by Friborg et al. (2003) and by Whiting and Chanton (2001). These results show that wetland restoration, for the purpose of restoring wetland habitats and biodiversity, may increase methane emission, but that restored wetlands can become a net sink of GHG's. Additionally, our observations suggest higher $\mathrm{CH}_{4}$ emissions in the case of a further rise of the water table. Hitherto, the effects of wetland restoration on methane emissions have been poorly quantified, but also other studies indicate an increase of methane emission (Tuittila et al., 2000; Van den Bos et al., 2003).

However, the effect of enhanced methane emission resulting from wetland restoration should be compared with the previous emission of drainage and agricultural use of the soil, with generally lower $\mathrm{CO}_{2}$-uptake, and extra $\mathrm{CO}_{2}$ emission from peat decomposition (Van den Bos et al., 2003). Unfortunately we do not have quantitative data from the GHG emissions at the site before the water level was raised. At two similar but drained peat land sites nearby an annual $\mathrm{NEE}$ of $157 \mathrm{~g} \mathrm{C} \mathrm{m}^{-2} \mathrm{yr}^{-1}$ (emission) and an annual NEE of $-62.4 \mathrm{~g} \mathrm{C} \mathrm{m}^{-2} \mathrm{yr}^{1}$ (uptake) over 2005 was observed (Veenendaal et al., personal communication, 2007 ${ }^{2}$ ). We have also modelled the $\mathrm{CO}_{2}$ and $\mathrm{CH}_{4}$ emission at the site for a $20 \mathrm{~cm}$ lower water table than the present water table (approximately the water table position before re-wetting) using the PEATLAND model (Van Huissteden et al., 2006), after calibrating the model for the site using our measurement data of the drier sites. This resulted in an increase of the $\mathrm{CO}_{2}$ emission from peat degradation of $330 \mathrm{~g} \mathrm{C} \mathrm{m}^{-2} \mathrm{yr}^{-1}$, which is 2.36 times the peat decomposition for the present situation. The $\mathrm{CH}_{4}$ emission from the land surface was reduced by $60 \%$ in the model results. The net GHG emission may have been $180 \%$ higher at a $20 \mathrm{~cm}$ lower water table, mainly by higher soil organic matter decomposition. In this result the effect of carbon export by harvest under agricultural land use in the past, and carbon uptake by vegetation in the present situation is not included. This suggests that although the area is presently only a small GHG sink, it may have been a considerably larger net source before rewetting. It should be noted also that the effects of higher $\mathrm{N}_{2} \mathrm{O}$ emission at agricultural

\footnotetext{
${ }^{2}$ Veenendaal, E., Kolle, O. Leffelaar, P., et al.: Land use dependent $\mathrm{CO}_{2}$ exchange and Carbon balance in two grassland sites on eutrophic drained peat soils, personal communication, 2007.
}

land use (Langeveld et al., 1997; Schils et al., 2006) were not considered here.

Acknowledgements. This research project is performed in the framework of the European research programme Carbo Europe (contract number GOCE-CT2003-505572) and the Dutch National Research Programme Climate Changes Spatial Planning (http://www.klimaatvooruimte.nl).

Edited by: J. Kesselmeier

\section{References}

Aerts, R. and Toet, S.: Nutritional controls on carbon dioxide and methane emission from Carex-dominated peat soils, Soil Biol. Biochem., 29, 1683-1690, 1997.

Alm, J., Schulman, L., Walden, J.. et al.: Carbon balance of a boreal bog during a year with an exceptionally dry summer, Ecology, 80(1), 161-174, 1999.

Aubinet, M., Grelle, A. Ibrom, A., et al.: Estimates of the annual net carbon and water exchange of forests: The EUROFLUX methodology, Adv. Ecol. Res., 30, 113-175, 2000.

Burgerhart, N.: Mogelijkheden voor koolstofopslag in Nederlandse ecosystemen, Wageningen, Leerstoelgroep Natuurbeheer en Plantenecologie, Wageningen University, 2001.

Ding, W. X., Cai, Z. C., Tsuruta, H., et al.: Factors affecting seasonal variation of $\mathrm{CH}_{4}$ concentration in water in a freshwater marsh vegetated with Carex lasiocarpa, Biol. Fert. Soils, 41(1), $1-8,2005$.

Drösler, M., Freibauer, A., Christensen, T. R., et al.: Observations and status of peatland greenhouse gas emissions in Europe, in: Observing the continental scale greenhouse gas balance, Chapter 8., edited by: Dolman, A. J., Valentini, R., and Freibauer, A., to be published in Springer Ecological series, , 2007.

Eugster, W. and Senn, W.: A Cospectral Correction Model for Measurement of Turbulent $\mathrm{N}_{2} \mathrm{O}$ Flux, Bound.-Lay. Meteorol., 74(4), 321-340, 1995.

Falge, E., Baldocchi, D., Olson, R., et al.: Gap filling strategies for long term energy flux data sets, Agr. Forest Meteorol., 107(1), 71-77, 2001.

Fiedler, S. and Sommer, M.: Methane emissions, groundwater levels and redox potentials of common wetland soils in a temperatehumid climate, Global Biogeochem. Cy., 14, 1081-1093, 2000.

Friborg, T., Soegaard, H., Christensen, T. R., et al.: Siberian wetlands: Where a sink is a source, Geophys. Res. Lett. 30(21), 2129, doi:10.1029/2003GL017797, 2003.

Gash, J. H. C. and Dolman, A. J.: Sonic anemometer (co)sine response and flux measurement I. The potential for (co)sine error to affect sonic anemometer-based flux measurements, Agr. Forest Meteorol., 119(3-4), 195-207, 2003.

Goulden, M. L., Munger, J. W., Fan, S. M., et al.: Measurements of carbon sequestration by long-term eddy covariance: Methods and a critical evaluation of accuracy, Glob. Change Biol., 2(3), 169-182, 1996.

Hope, D., Palmer, S. M., Billett, M. F., et al.: Variations in dissolved $\mathrm{CO}_{2}$ and $\mathrm{CH}_{4}$ in a first-order stream and catchment: an investigation of soil-stream linkages, Hydrol. Processes, 18(17), 3255-3275, 2004. 
IPCC: IPCC Third Assessment Report, Climate Change 2001, Cambridge Univ. Press, Cambridge, UK, 2001.

Janssens, I. A., Freibauer, A., Schlamadinger, B., et al.: The carbon budget of terrestrial ecosystems at country-scale - a European case study, Biogeosciences, 2, 15-26 2005.

Kaimal, J. C. and Finnigan J. J.: Atmospheric boundary layer flows, their structure and management, New York, Oxford University Press, 1994.

Langeveld, C. A., Segers, R., Dirks, B. O. M., et al.: Emissions of $\mathrm{CO}_{2}, \mathrm{CH}_{4}$ and $\mathrm{N}_{2} \mathrm{O}$ from pasture on drained peat soils in the Netherlands, Eur. J. Agron., 7(1-3), 35-42, 1997.

Lloyd, C. R., Bessemoulin, P., Cropley, F. D., et al.: A comparison of surface fluxes at the HAPEX-Sahel fallow bush sites, J. Hydrol., 189(1-4), 400-425, 1997.

Lloyd, J. and Taylor, J. A.: On the Temperature-Dependence of Soil Respiration, Funct. Ecol., 8(3), 315-323, 1994.

Nakai, T., Van der Molen, M. K., Gash, J. H. C., et al.: Correction of sonic anemometer angle of attack errors, Agr. Forest Meteorol., 136(1-2), 19-30, 2006.

Obdam, A. and Cleveringa, P.: Gas in de ondiepe ondergrond, Stromingen 7, deel 2, 35-46, 2001.

Regina, K., Syvasalo, E., Hannukkala, A., et al.: Fluxes of $\mathrm{N}_{2} \mathrm{O}$ from farmed peat soils in Finland, Eur. J. Soil Sci., 55(3), 591599, 2004

Reichstein, M. Falge, E., Baldocchi, D., et al.: On the separation of net ecosystem exchange into assimilation and ecosystem respiration: review and improved algorithm, Glob. Change Biol., 11(9), 1424-1439, 2005.

Roulet, N. T., Lafleur, P. M., Richard, P. J. H., et al.: Contemporary carbon balance and late Holocene carbon accumulation in a northern peatland, Glob. Change Biol., 13(2), 397-411, 2007.

Schils, R. L. M, Verhagen, A., Aarts, H. F. M., et al.: Effect of improved nitrogen management on greenhouse gas emissions from intensive dairy systems in the Netherlands, Glob. Change Biol., 12, 382-391, 2006.

Soussana, J. F.: Towards a full accounting of the greenhouse gas balance of European grasslands, in: Observing the continental scale greenhouse gas balance, Chapter 9, edited by: Dolman, A. J., Valentini, R., and Freibauer, A., to be published in Sprinter Ecological series, 2007.

Smith, K. A., Ball, T., Conen, F., et al.: Exchange of greenhouse gases between soil and atmosphere: interactions of soil physical factors and biological processes, Eur. J. Soil Sci., 54-4, 779-791, 2003.

Strack, M., Waller, M. F., Waddington, J. M., et al.: Sedge succession and peatland $\mathrm{CH}_{4}$ dynamics: A potential feedback to climate change, Ecosystems, 9(2), 278-287, 2006.

Stull, R. B.: An Introduction to boundary layer meteorology, Dordrecht, Kluwer Academic Publishers, Atmospheric Sciences Library, Chapter 8, 1988.

Sundh, I., Nilsson, M., Mikkelä, C., et al.: Fluxes of Methane and Carbon Dioxide on peat-mining Areas in Sweden, Ambio, 29, 499-503, 2000.
Treat, C. C., Bubier, J. L., Varner, R. K., et al. Timescale dependence of environmental and plant-mediated controls on $\mathrm{CH}_{4}$ flux in a temperate fen, J. Geophys. Res.-Bio., 112(G1), G01014, doi:10.1029/2006JG000210, 2007.

Tuittila, E. S., Komulainen, V. M., Vasander, H., et al.: Methane dynamics of a restored cut-away peatland, Glob. Change Biol., 6, 569-581, 2000.

Van de Griend, A. A.: Inleiding tot de hydrodynamica en hydraulica, Amsterdam, Instituut voor Aardwetenschappen Vrije Universiteit, Hoofdstuk 6, 1989.

Van den Bos, R., Van Huissteden, J., and Van de Plassche, O.: A model-based assessment of $\mathrm{CO}_{2}$ and $\mathrm{CH}_{4}$ fluxes in coastal peatlands (Western Netherlands) for different climate and management scenarios, in: Human influences on carbon fluxes in coastal peatlands; process analysis, quantification and prediction, edited by: van den Bos, R. M., Thesis, Vrije Universiteit, p. 91-110, 2003.

Van den Pol-Van Dasselaar, A., van Beusichem, M. L., Oenema, O., et al.: $\mathrm{CH}_{4}$ emissions from wet grasslands on peat soil in a nature preserve, Biogeochemistry, 44(2), 205-220, 1999.

Van den Pol-van Dasselaar, A., van Beusichem, M. L., Oenema, O., et al.: Effects of soil moisture content and temperature on $\mathrm{CH}_{4}$ uptake by grasslands on sandy soils, Plant and Soil, 204(2), 213-222, 1998a.

Van den Pol-van Dasselaar, A., Corre, W. J., Prieme, A., et al.: Spatial variability of $\mathrm{CH}_{4}, \mathrm{~N}_{2} \mathrm{O}$, and $\mathrm{CO}_{2}$ emissions from drained grasslands, Soil Sci. Soc. Am. J., 62(3), 810-817, 1998b.

Van der Molen, M. K., Gash, J. H. C., Elbers, J. A., et al.: Sonic anemometer (co)sine response and flux measurement - II. The effect of introducing an angle of attack dependent calibration, Agr. Forest Meteorol., 122(1-2), 95-109, 2004.

Van der Molen, M. K., Zeeman, M. J., Lebis, J., et al.: EClog: A handheld eddy covariance logging system, Comput. Electron. Agr., 51(1-2), 110-114, 2006.

Van Huissteden, J., Maximov, T. C., and Dolman, A. J.: High methane fluxes from an arctic floodplain (Indigirka lowlands, eastern Siberia), J. Geophys. Res., 110, G02002, doi:10.1029/2005JG000010, 1-8, 2005.

Van Huissteden, J., Van den Bos, M., Marticorena Alvarez, I.: Modelling the effect of water-table management on $\mathrm{CO}_{2}$ and $\mathrm{CH}_{4}$ fluxes from peat soils, Neth. J. Geosci., 85, 3-18, 2006.

Van't Hoff, J. H.: Lectures on Theoretical and Physical Chemistry, Part I. Chemical Dynamics (translated by Lehfeldt, R. A.), Edward Arnold, London, pp. 224-229, 1898.

Wagner, D., Pfeiffer, E. M., and Bock, E.: Methane production in aerated marshland and model soils: effects of micro flora and soil texture, Soil Biol. Biochem., 31(7), 999-1006, 1999.

Whiting, G. J. and Chanton. J. P.: Greenhouse carbon balance of wetlands: $\mathrm{CH}_{4}$ emission versus carbon sequestration, Tellus Ser B, 53(5), 521-528, 2001.

Worrall, F., Burt, T., Adamson, J., et al.: Fluxes of dissolved $\mathrm{CO}_{2}$ and inorganic carbon from an upland peat catchment: implications for soil respiration, Biogeochemistry, 73(3), 515-539, 2005 . 